\title{
Technology and Education: A Merger with the Past, Present, and Future
}

\author{
Marion G. Ben-Jacob1 ${ }^{1}$, Allan H. Glazerman' ${ }^{2}$ \\ ${ }^{1}$ Department of Mathematics and Computer Sciences, Mercy College, Dobbs Ferry, NY, USA \\ ${ }^{2}$ Department of Nonprofit Management, Gratz College, Melrose Park, PA, USA \\ Email: mbenjacob@mercy.edu
}

How to cite this paper: Ben-Jacob, M. G., \& Glazerman, A. H. (2021). Technology and Education: A Merger with the Past, Present, and Future. Open Journal of Social Sciences, 9, 39-42.

https://doi.org/10.4236/jss.2021.94004

Received: July 10, 2020

Accepted: April 3, 2021

Published: April 6, 2021

Copyright $\odot 2021$ by author(s) and Scientific Research Publishing Inc. This work is licensed under the Creative Commons Attribution International License (CC BY 4.0).

http://creativecommons.org/licenses/by/4.0/

\begin{abstract}
Technology has been assimilated into our educational system on an in-depth level. This paper reflects on its changes to the learning environment. It presents a synopsis of the necessary focus of educators for the future.
\end{abstract}

\section{Keywords}

Technology, Education, Online Learning, Covid-19

\section{Introduction}

As technology became more and more integrated into society, so did the uncertainty of how it would alter our way of life. This paper addresses the aspect of the change in our culture and habits promoted by the use of technology in education. To emphasize the evolution in a logical manner, the discussion includes different time-periods.

Technology is becoming embedded in every facet of our day-to-day lives, influencing what we think and feel and how we interact with others. It has brought about unprecedented changes in how we store and communicate information, and as it becomes more integrated into society, so too does the uncertainty of how it will change us and our interactions.

\section{The Past}

Prior to the outbreak of the Covid-19 pandemic, institutions of higher learning offered courses online, but, despite the obvious benefits of time commitment and geographic location, there were those who felt remote courses could not replace onsite courses. Of course, the latter venue was never meant to replace the former; rather it was an alternative means of education, to be offered in con- 
junction with and not in lieu of onsite education. Remote learning provided a great opportunity to many who would not be able to further their education otherwise (Ben-Jacob \& Wang, 2020).

Social media such as Facebook, Instagram, and FaceTime are grounded in technology. People were not only interacting with their friends, but were able to communicate with family, and network with peers with whom they may have lost contact over the years (Dotdash, 2020). The familiarity with social media helped many students become online learners.

\section{The Present}

The outbreak of Covid-19 and our response of social distancing and sheltering in place meant a drastic change in our reliance on technology that, fortunately, was already in place and integrated into the different facets of our lives. Online courses, for example, were already being offered at most institutions of higher learning, but whereas previously students had the option of enrolling in onsite courses, now, during the pandemic, that was no longer a live option. Similarly, faculty who had previous shied away from teaching remotely now faced a necessity with a timed steep learning curve. Recent events, in short, offered no choice to students or faculty.

With the increase in the use of technology comes some caveats that must be addressed with students. User-created content is prone to errors, bias, and inconsistencies. Additionally, limited restrictions to publishing on the Internet necessitate the verification of sources. Many students are not aware of the concept of plagiarism, and even if they are, they need to be familiar with the form for documentation, different from those of hard copy sources. In addition, those who are not the original authors can modify information on the Internet.

At the time of the Covid-19 outbreak, younger children were adept at using technology, but not at learning on ZOOM sessions. Elementary and high school education has undergone a significant transformation. For older students this will hopefully motivate them to begin their independent, lifelong learning path. Discussions are continuing with respect to increasing the effectiveness of online learning for children with special needs.

Teachers and professors are online using the aforementioned tools as well as the Learning Management Systems (LMSs) like Blackboard, Talent LMS, Google Classroom and others (Software Advice, 2020). Different models head the list of discussion topics for the fall semester. Flexibility is the norm at present. Some of the approaches other than completely online or onsite are the following:

- Block or Module Courses-course material would be divided into blocks or modules and as the need arises each block or module could be online or onsite;

- Structure Gap Year/Semester-provide the students with a hiatus in their studies;

- Onsite classes for residential students-this would facilitate social distancing, 
- Offer multiple sections of courses, both online and onsite;

- Lecture material can be videoed and then recitation sections can be limited to a smaller number of students;

- Combination of Onsite and Online-a traditional class can have the student body divided in two groups; each group attends onsite every other week or one of two days/week and the other group the other days; lectures can be posted online via notes or videos;

- Onsite courses can be synchronous with ZOOM and students can be in the classroom or off campus as they so opt (Maloney \& Kim, 2020).

It is clear that the use of technology has pervaded many facets of people's lives. People are working remotely, sharing files and information and using video conferencing tools such as ZOOM, Cisco Webex Meetings, GoToMeeting, Google Hangouts and others more than ever. These tools are being used for education purposes as well (Software Advice, 2020).

Young children are particularly rising to the occasion. Lacking the adult concern of "not looking smart", they are using their phones, IPads, and computers for school sessions and communication with their friends as well as playing the usual video games online.

\section{The Future}

Although it is always difficult to predict the future, we can safely say that, based on the response to the pandemic, life situations will never be the same. Education was forced to go totally online during the spread of Covid-19. This transition was quite abrupt. At the early education levels, it entailed teachers, parents, and students becoming familiar with the technology. Parents, for the first time in a long time, had to become more directly involved with their children's education. In the scheme of life, this is a positive. Moreover, while we do not know what per cent of post Covid-19 education will be virtual, we can speculate that, given the generally progressive nature of technology, the new familiarity with it, and the involvement of parents in their children's education, the percentage will be significantly higher than in pre-Covid-19 times.

At the college and university levels, most institutions had a component of online or remote learning before the Covid-19 outbreak. Those faculty members that did not teach remotely were caught unawares and were compelled to learn quickly. Many students were familiar with the online platforms and adapted quickly, especially with the help of their institution's IT department, if necessary. Continuing with remote learning provides the students with the flexibility of studying more independently and at their own pace. From a pedagogical perspective, we want our students to become life-long learners as well as independent learners. We want to spark their intellectual curiosity so they will be motivated to increase their knowledge base. An educated society makes a stronger and more productive society.

Of interest is the influence of future education as related to the learning pyramid (Figure 1). 
THE

\section{LEARNING PYRAMID}

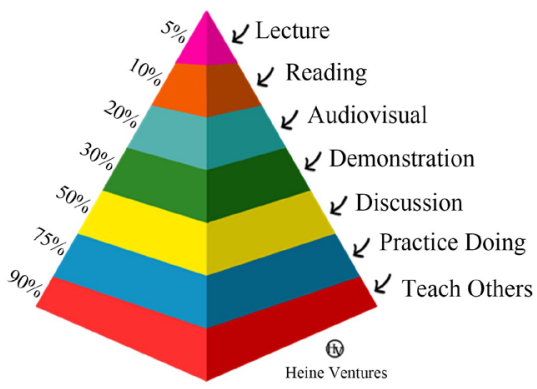

Figure 1. The learning pyramid (Learning Pyramid, 2020).

The top four levels are considered passive learning and the bottom four active learning. As educators, it is imperative that we engage our students in active learning so their retention of the material and associated algorithms remains high. We must implement and support educational motivation on the parts of our students so they will continue learning now with the new environment and continue to be lifelong learners.

It is evident that the spread of the virus has considerably influenced the different facets of our lives. We need to embrace the changes and incorporate the alternatives as a way to enhance our lives and the future education of our students.

\section{Conflicts of Interest}

The authors declare no conflicts of interest regarding the publication of this paper.

\section{References}

Ben-Jacob, M., \& Wang, D. (2020). Global Learning and Its Implementations. In P. Kommers, A. B. N. Viana, T. Issa, \& P. Isaías (Eds.), Proceedings of the 7th International Conference on Educational Technologies. São Paulo.

https://doi.org/10.33965/icedutech2020 202002R016

Dotdash (2020). What Is Social Media?

https://www.thebalancesmb.com/what-is-social-media-2890301

Learning Pyramid (2020).

https://www.google.com/search?sxsrf=ALeKk02Nan80QRmTxz4tAW4x5uxT8th93w\% 3A1593

Maloney, E., \& Kim, J. (2020). 15 Fall Scenarios. Inside Higher Education. https://www.insidehighered.com/digital-learning/blogs/learning-innovation/15-fall-sce $\underline{\text { narios }}$

Software Advice (2020). https://www.softwareadvice.com/ 